\title{
VIDEO-ASSISTED TREATMENT OF RECURRENT AND COMPLICATED FISTULOUS FORMS OF CHRONIC PARAPROCTITIS
}

\author{
Tsygankov P.V. ${ }^{1}$, Groshilin V.S. ${ }^{1}$, Smolkina A.V. ${ }^{2}$, Sultanmuradov M.I. ${ }^{1}$, \\ Mrykhin G.A. ${ }^{1}$ \\ ${ }^{1}$ Rostov State Medical University, Rostov-on-Don, e-mail: groshilin@yandex.ru; \\ ${ }^{2}$ Ulyanovsk State University, Ulyanovsk, e-mail: smolant1@yandex.ru
}

Aims.

The aim of the study was to evaluate the efficacy and finding benefits of the video-assisted fistula treatment method using fistuloscopy compared to conventional surgical treatment methods for complex forms of chronic paraproctitis, and transsphincteric and extrasphincteric, relapsing rectal fistulas.

Materials and methods.

A comprehensive analysis was carried out of the results of surgical treatment of 228 patients with chronic paraproctitis, transsphincteric, extrasphincteric, including relapsing, rectal fistulas, subdivided into three groups (the main and two control ones) depending on the applied methods of surgical treatment of chronic paraproctitis. The results of surgical treatment of pararectal fistulas in the three study groups were compared. The treatment efficacy was assessed based on the results of early and late postoperative period.

Results.

It is found that the use of video-assisted fistula treatment method with fistuloscopy excludes an extensive surgical wound in the perianal region, which greatly reduces the probability of its secondary infection and trauma of the sphincter, thereby actually excludes the occurrence of insufficiency. The use of video-assisted fistula treatment method helped reduce the number of postoperative complications.

Conclusions. Given the final results $(92.7 \%$ favourable outcomes), we recommend the video-assisted fistula treatment method for widespread practical implementation.

Keywords: pararectal fistula, fistuloscopy, relapsing fistula, paraproctitis.

\section{INTRODUCTION.}

Fistulas occupy the first place in the rank of complications of chronic paraproctitis [1;2]. At the present stage of coloproctology development, the final treatment of this pathology is surgical fistula dissection $[2 ; 3]$. Leading surgeons in this area proposed numerous methods for rectal fistula surgery [4]. However, such surgery is often associated with complications in pararectal intercellular space, which are accompanied by continuous development and often relapse of the inflammatory process $[5 ; 6]$.

The most severe post-surgical complication is anal sphincter failure after incompletely radical surgery and long-term treatment $[7 ; 8]$. Unfortunately, the formed scars in the pararectal area often do not allow for the complete dissection of pathologically altered tissues [9; 10]. Thus, any surgical method of treatment intended for the reinforcement of rectal walls and the wound has its advantages and disadvantages.

The implementation of new effective surgical methods for the treatment of rectal fistulas, especially in cases of relapse, is an acute task in modern surgery.

The study was aimed at evaluating the effectiveness and identifying the benefits of the video-assisted method of fistula treatment using fistuloscopy in comparison with traditional 
methods of surgical treatment for complicated forms of chronic paraproctitis and transsphincteric and extrasphincteric, relapsing rectal fistula.

MATERIALS AND METHODS. A prospective blind randomized study (with preliminary stratification of cases by the severity of pathological process) on the effectiveness of the treatment of 228 patients with chronic paraproctitis fistulas was performed at the surgical department of the clinics at Rostov State Medical University in 2012-2017. The study included patients with transsphincteric and extrasphincteric fistulas, including relapse forms (156 men (67.8\%) and 72 women $(31.2 \%)$ ). The mean age of men was 31.5 \pm 7.9 years old and the mean age of women was 47.1 \pm 9.4 years old. By the duration of the disease, patients were divided as follows: less than 6 months -26 patients $(11.4 \%)$, from 6 months to 1 year -86 patients $(37.7 \%)$, from 1 to 3 years -46 patients $(20.2 \%)$, from 3 to 5 years -45 patients $(19.7 \%)$, more than 5 years -25 patients $(11 \%)$. The study exclusion criteria were intrasphincteric pararectal fistulas, fistulas associated with specific diseases, and rectal neoplasms (including patients with radical surgery for cancer).

There were 34 patients with transsphincteric fistulas (14.9\%), 5 of them had relapse fistulas (2.2\%); 24 patients with extrasphincteric fistulas of the 1st degree (10.5\%), 6 of them had relapse fistulas (2.6\%); 29 patients had extrasphincteric fistulas of the 2nd degree (12.7\%), 6 of them had relapse fistulas (2.6\%); 96 patients had extrasphincteric fistulas of the 3rd degree (42.1\%), 17 of them had relapse fistulas (7.4\%); and 45 patients had extrasphincteric fistulas of the 4th degree (19.7\%), 11 of them had relapse fistulas $(4.8 \%)$. There were 51 patients $(22.4 \%)$ with concomitant pathology of the rectum, which required simultaneous surgical correction. Chronic hemorrhoids of the 3rd-4th degree was revealed in 21 patients (hemorrhoidectomy), chronic anal fissure - in 27 patients (dissection of the anal fissure, if necessary, dosed dilation of the anal canal), adenomatous polyps of the anal canal - 3 patients (polypectomy). The volume of surgical treatment was determined by the type of fistula and duration of the disease, and corresponded with the recommendations of the "Russian Association of Coloproctology". In the main group, the patients were treated using the technology of video-assisted anal fistula treatment (VAAFT, CarlStorz, Germany). Two hundred twenty-eight patients that complied with the study criteria were split into three groups (main group and two control groups) depending on the used surgical treatment for chronic paraproctitis, complicated transsphincteric and extrasphincteric, relapse rectal fistulas.

The main group included 55 patients $(24.1 \%)$ that were treated using the technology of video-assisted anal fistula treatment. Control group I included 89 patients (39.1\%) that underwent excision of the fistula with the liquidation of the internal lumen, suturing of its stump in the perineal wound (including by the method of Ryzhykh). Control group II included 84 patients (36.9\%) that underwent radical excision of the fistula with segmented proctoplasty (transfer of the U-shaped musculomucosal graft or layer-by-layer flap of the rectum with its fixation in the anal canal).

The effectiveness of the treatment was evaluated by the results of the immediate and remote postoperative period. The results were estimated as "good" in recovered patients that did not have 
postoperative complications and relapse of pathology. The clinical outcome was estimated as "satisfactory" in patients with some complications that completely resolved after conventional treatment or in patients that developed secondary sphincter weakness (revealed by postoperative anorectal manometry) without clinical manifestations of fecal incontinence. The results were unsatisfactory when patients had disease relapse, which required repeated surgical treatment, and complications that did not resolve after conventional treatment.

The period of postoperative monitoring was 12 months.

Statistical analysis of the obtained data was performed using the computer software Microsoft Excel 2007, STATISTICA 10 and included the calculation of the arithmetic mean (M), standard error of the mean $(\mathrm{m})$, and standard deviation $(\sigma)$. The evaluation of the normality of distribution of the parameters was performed by the mean values.

The authors used the method of parametric statistics (Student's t-test). The differences were statistically significant at $(\mathrm{p})>95 \%(\mathrm{p}<0.05)$. In the rest cases, the differences were considered statistically insignificant $(\mathrm{p}>0.05)$.

The study protocol followed guidelines for experimental investigation with human subjects in accordance with the Declaration of Helsinki and was approved by the ethics committee. Written informed consent was obtained from each patient (or an official representative) before the study.

\section{RESULTS.}

The treatment results showed that the video-assisted method using fistuloscopy is not only a treatment step but it also has important significance for the choice of intra-operative tactics. Fistuloscopy provided the precise topical location of the fistula passage, its branches, and blind residual cavities. It allowed the authors to correct preoperative diagnostic discrepancies in topography. Due to the accumulation of clinical experience of the application of VAAFT, the treatment step included electrocoagulation of fistula passage walls, excision of necrotic tissues with a sharpened brush, suturing of internal fistula passage, and sealing of residual canal with twocomponent glue BioGlue. The final postoperative distribution of patients by the degree of severity of fistula in the studied groups is presented in Table 1.

Table 1. The distribution of patients by the degree of severity of the fistula in the studied groups

\begin{tabular}{|l|l|l|l|}
\hline \multicolumn{1}{|c|}{ Study groups } & \multicolumn{1}{|c|}{$\begin{array}{c}\text { Main } \\
\text { group, } \\
\mathbf{n = 5 5}\end{array}$} & $\begin{array}{c}\text { Control group } \\
\text { I, } \\
\text { the stula localization in regards to }\end{array}$ & \multicolumn{1}{c|}{$\begin{array}{c}\text { Control group } \\
\text { II, } \\
\mathbf{n = 8 4}\end{array}$} \\
\hline Transsphinteric fistula & $\begin{array}{l}6(10.9 \%), 2 \text { of } \\
\text { them are recurrent }\end{array}$ & $\begin{array}{l}16(18 \%), 2 \text { of } \\
\text { them are recurrent }\end{array}$ & $\begin{array}{l}12(14.3 \%), 1 \text { of them is } \\
\text { recurrent }\end{array}$ \\
\hline $\begin{array}{l}\text { Extrasphincteric fistula, I } \\
\text { degree }\end{array}$ & $\begin{array}{l}\text { 6(10.9\%), } 2 \text { of } \\
\text { them are recurrent }\end{array}$ & $\begin{array}{l}7(7.9 \%), 2 \text { of } \\
\text { them are recurrent }\end{array}$ & $\begin{array}{l}11(13.1 \%), 2 \text { of them } \\
\text { are recurrent }\end{array}$ \\
\hline $\begin{array}{l}\text { Extrasphincteric fistula, II } \\
\text { degree }\end{array}$ & $\begin{array}{l}7(12.7 \%), 2 \text { of } \\
\text { them are recurrent }\end{array}$ & $\begin{array}{l}13(14.6 \%), 2 \text { of } \\
\text { them are recurrent }\end{array}$ & $\begin{array}{l}9(10.7 \%), 2 \text { of } \\
\text { them are recurrent }\end{array}$ \\
\hline
\end{tabular}




\begin{tabular}{|l|l|l|l|}
\hline $\begin{array}{l}\text { Extrasphincteric fistula, III } \\
\text { degree }\end{array}$ & $\begin{array}{l}23(41.9 \%), 4 \text { of } \\
\text { them are recurrent }\end{array}$ & $\begin{array}{l}39(43.8 \%), 8 \text { of } \\
\text { them are recurrent }\end{array}$ & $\begin{array}{l}34(40.5 \%), 5 \text { of them } \\
\text { are recurrent }\end{array}$ \\
\hline $\begin{array}{l}\text { Extrasphincteric fistula, IV } \\
\text { degree }\end{array}$ & $\begin{array}{l}13(23.6 \%), 3 \text { of } \\
\text { them are recurrent }\end{array}$ & $\begin{array}{l}14(15.7 \%), 4 \text { of } \\
\text { them are recurrent }\end{array}$ & $\begin{array}{l}18(21.4 \%), 4 \text { of them } \\
\text { are recurrent }\end{array}$ \\
\hline Recurrent fistula, total & $\mathbf{1 3}(\mathbf{2 3 . 6 \% )}$ & $\mathbf{1 8 ( 2 0 . 2 \% )}$ & $\mathbf{1 4}(\mathbf{1 6 . 7 \% )}$ \\
\hline
\end{tabular}

It should be noted that using VAAFT in the main group excluded the necessity in a vast postoperative surgical wound in the perianal area, which significantly decreased the risk of secondary infection, traumatization of the sphincter and prevented the development of sphincter failure. Another important fact is the exclusion of antibacterial therapy in the postoperative period. Antibacterial therapy was indicated in both control groups. In the main group, antibacterial therapy was given only to two patients that developed an inflammatory reaction in the projection of the external fistula opening. Antibacterial therapy included a 3rd-generation antibacterial drug of the cephalosporin group in combination with metronidazole until the normalization of hyperthermia and leukocytosis.

The analysis of the duration of the introduction of NSAID with non-selective inhibition of cyclooxygenase-1 and cyclooxygenase-2 (30 mg TID, IV) showed that this period reduced by $1.7 \pm 0.28$, on average, in the main group. The analysis of the duration of hyperthermia above $37^{\circ} \mathrm{C}$ showed that it was $5.43 \pm 1.32$ days in Control group I, $4.9 \pm 1.54$ days in Control group II, and $3.9 \pm 1.73$ days in the main group. A similar tendency was observed during the analysis of the average level of leukocytes. A decrease in the level of leukocytes to $\leq 9 \times 10^{9} / \mathrm{L}$ in Control group I was observed for $8.7 \pm 2.6$ days, in Control group II - for $6.9 \pm 3.1$ days, in the main group - for $5.6 \pm 3.1$ days. The postoperative inpatient period in the main group was $5.23 \pm 2.4$ days in comparison with 12.7 \pm 3.1 days in Control group I and 13.21 \pm 4 .0 days in Control group II.

The results of the treatment are presented with the account of all the complications, including remote ones. There were four complications in the main group (7.3\%), 30 - in Control group I (33.7\%), 23 - in Control group II (27.4\%). In total, there were four cases of further fistulas relapse in the main group (7.2\%). In one case, the relapse fistula resolved after conventional treatment and, in three cases, repeated surgery was performed in inpatient conditions. The ratio of complications is presented in Diagrams (Figures A-C) 


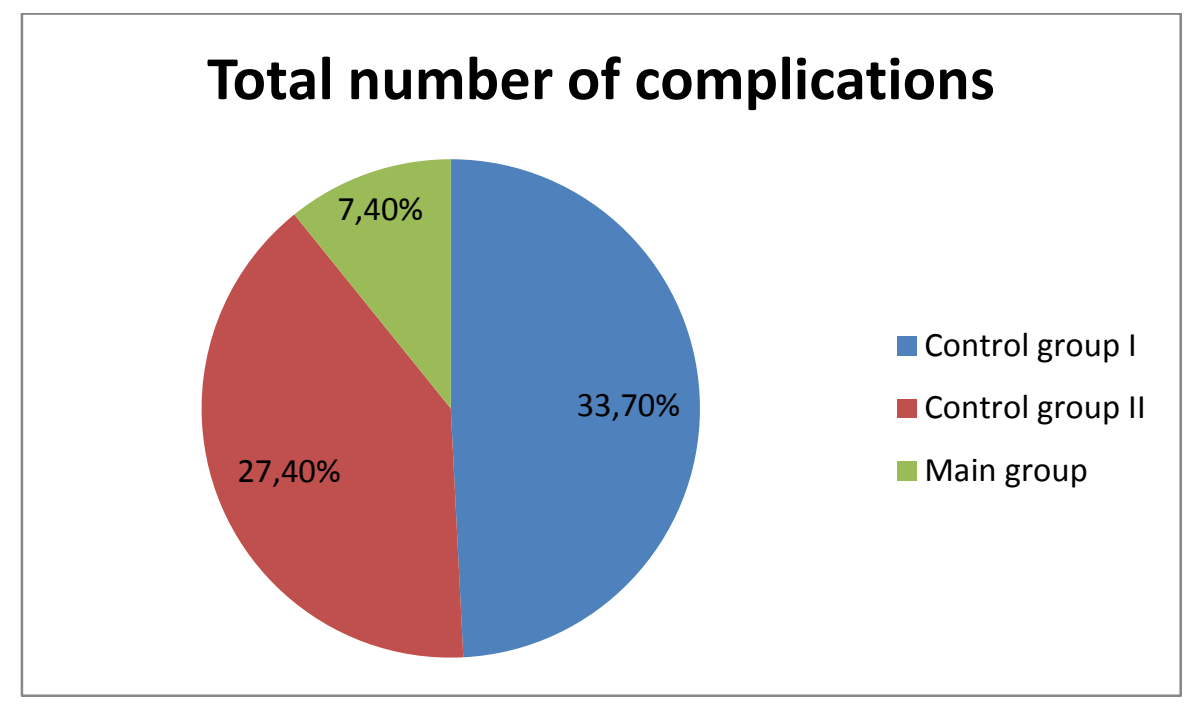

Figure A

\section{Early postoperative complications}

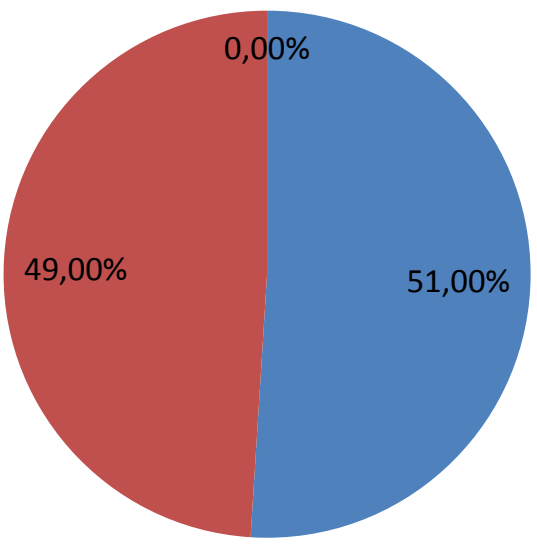

Control group I

- Control group II

Main group

Figure B

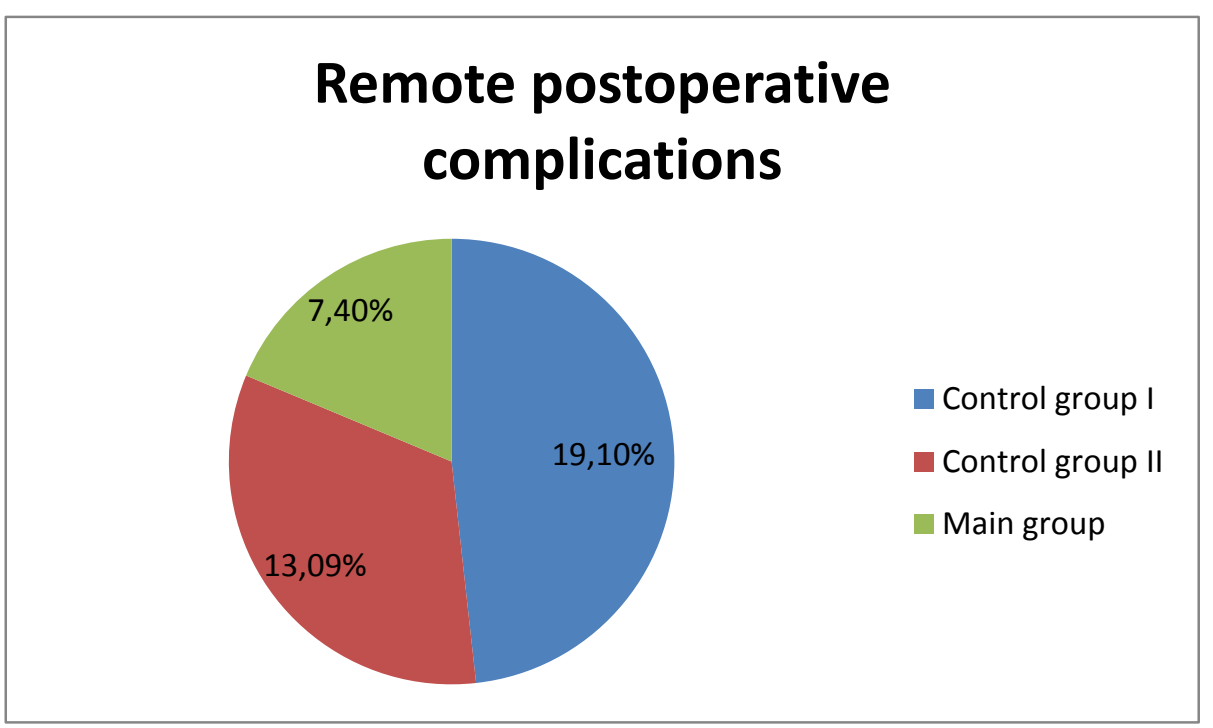

Figure $\mathbf{C}$ 
In Control group I, there were 30 cases with postoperative complications (33.7\%) including 13 early postoperative complications ( 2 cases of hemorrhages, 1 perinatal abscess, 10 cases of inflammatory infiltrates and suppuration of the surgical wound) and 17 relapses and remote complications (14 cases of relapse fistulas that required repeated surgery and 3 cases of anal sphincter weakness that was verified with a manometer).

In Control group II, there were 23 cases with complications in the postoperative period (27.4\%) including 12 early postoperative complications ( 1 hemorrhage, 6 cases of retraction (or focal necrosis) of the transferred flap, 5 cases of inflammatory infiltrates and suppuration of the postoperative wound that did not lead to a relapse) and 11 cases with remote unsatisfactory results ( 9 relapses that required repeated surgical treatment and 2 cases of anal sphincter failure of the 1st degree). Good results with no complaints in the remote period were obtained in 51 patients from the main group (92.7\%), 59 patients from Control group I (66.3\%), and 61 patients from Control group II (72.6\%). Satisfactory results after the resolution of complications were observed in one patient from the main group (1.8\%), 13 patients from Control group I (14.6\%) and 12 patients from Control group II (14.2\%). There were 3 cases with unsatisfactory results in the main group (5.5\%), 17 cases - in Control group I (19.1\%) and 11 cases in Control group II (13.1\%).

\section{CONCLUSIONS.}

The application of the VAAFT method in patients with complicated and relapse fistulas revealed significant benefits in comparison with traditional methods, which was proved by stable positive results and minimum complications. The method confirmed high clinical effectiveness and high safety achieved due to the minimum injury rates.

In patients with relapse and complicated extrasphincteric fistula, the risk of traumatic injury of earlier discredited and injured components of the sphincter is maximal, which provides a high risk of the development of sphincter failure and, as a result, fecal incontinence.

In the main group, due to the application of the VAAFT method, it was possible to avoid these complications by minimizing the risk of their development. It can be concluded that the best remote results were obtained in the main group $(92.7 \%$ - good, $1.8 \%$ - satisfactory, 5.5\% unsatisfactory) in comparison with Control group I (66.3\% - good, 14.6\% - satisfactory, 19.1\% unsatisfactory) and Control group II (72.6\% - good, 14.2\% - satisfactory, 13.1\% - unsatisfactory).

The obtained results were achieved in the main group due to the application of a modified VAAFT technology and fistuloscopy techniques that provided a significant decrease in the level of early and remote postoperative complications.

The obtained data provides grounds for the recommendation of VAAFT in the treatment of complicated transsphincteric and extrasphincteric and relapse fistulas. 
FINANCIAL SUPPORT AND SPONSORSHIP

Nil.

\section{CONFLICTS OF INTEREST}

The authors declare no conflict of interest

\section{SUPPLEMENTARY DATA (DOI)}

\section{REFERENCES}

1. Cherkasov D.M. Justification of the tactics of surgical treatment of extrasphincter fistula of the rectum: abstract of the dissertation of the candidate of medical sciences [Obosnovanie taktiki khirurgicheskogo lecheniia ekstrasfinkternykh svishchei priamoi kishki: avtoreferat dissertatsii kandidata meditsinskikh nauk]. Rostov-on-Don, 2009, 29 p.

2. Slepykh N.V., Il'kanich A.Ia. Fistuloscopy in the treatment of rectal fistula [Fistuloskopiia pri lechenii svishchei priamoi kishki] Coloproctology - Koloproktologiia, 2016, vol. 56, no 2, Suppl. 1. p. 41.

3. Meinero P., Mori L. Video-assisted anal fistula treatment (VAAFT): a novel sphinctersaving procedure for treating complex anal fistulas. Techniques in Coloproctology. 2011, vol. 15, no 4, pp. 417-422, doi10.1007/s10151-011-0769-2.

4. Stazi A., Giarratano G., Mazzy M. Sphincter-saving treatment of recurrent complex anal fistula with Video-Assisted Anal Fistula Treatment (VAAFT): a prospective study. Colorectal Disease, 2014, vol. 16, no 3, p. 4.

5. Groshilin V.S., Sultanmuradov M.I., Moskovchenko A.N. Modern aspects prevention of complications after obstructive resection of the distal colon [Sovremennye aspekty profilaktiki oslozhnenii posle obstruktivnykh rezektsii distal'nykh otdelov tolstoi kishki]. Fundamental Research - Fundamental'nye issledovaniia, 2013, vol. 1, no. 9, pp. 24-27.

6. Charyshkin A.L., Soldatov A.A., Dementev I.N. Comparative estimation of surgical treatment of patients with chronic paraproctitiS [Sravnitel'naia otsenka khirurgicheskogo lecheniia bol'nykh s khronicheskim paraproktitom]. Modern problems of science and education - Sovremennye problemy nauki i obrazovaniia, 2012, no. 4, available at: http://science-education.ru/ru/article/view?id=6478. (accessed 12.03.2019).

7. Seidinov Sh.M., Ashurmetov R.I., Babakhanov A.T. at al. Plastic correction results in patients with extrasfincteric pararectal fistulas [Rezul'taty plasticheskoi korrektsii u bol'nykh s ekstrasfinkternymi pararektal'nymi svishchami]. Bulletin KazNMU - Vestnik KazNMU, 2015, no 1, pp. 219-222.

8. Gabibov S.G., Shodiev N.A. Modified video-assisted method of treating rectal fistula [Modifitsirovannyi videoassistirovannyi metod lecheniia svishchei priamoi kishki] Coloproctology Koloproktologiia, 2014, vol. 49, no 3, Suppl. 1, pp. 17-18.

9. Ektov V.N., Popov R.V., Vollis E.A Fibrin glue as an option for improvement of surgical treatment 
of fistula-in-a [Vozmozhnosti uluchsheniia rezul'tatov khirurgicheskogo lecheniia priamokishechnykh svishchei s ispol'zovaniem fibrinovogo kleia]. Coloproctology Koloproktologiia, 2013, vol. 44, no 2, pp. 44-50.

10. Song Ho K. New Techniques for Treating and Anal Fistula. Journal of the Korean Society of Coloproctology, 2012, vol. 28, no 1, pp. 7-12, doi 10.3393/jksc.2012.28.1.7 